TECTONICS, VOL. 7, NO. 3, PAGES 447-462, JUNE 1988

\title{
EARLY MESOZOIC RIFT BASINS OF EASTERN NORTH AMERICA AND THEIR GRAVITY ANOMALIES: THE ROLE OF DETACHMENTS DURING EXTENSION
}

\author{
Robin E. Bell ${ }^{1}$, Garry D. Karner, and Michael S. Steckler \\ Lamont-Doherty Geological Observatory of \\ Columbia University, Palisades, New York
}

\begin{abstract}
Two end-member models of extension involving detachments have been developed. One model incorporates a fault that soles at midcrustal level overlying a broad region of pure shear in the lower crust. The second, referred to as the simple shear model, includes a detachment continuing through the entire crust and terminating in a region of concentrated extension in the lower crust. Both models predict basins with no localized thermal effect. With the inclusion of flexural isostasy, both models predict footwall uplift whose amplitude and wavelength are controlled by the detachment geometry and the lithospheric strength. A gravity anomaly over the hanging wall block distinguishes the simple shear model from the intracrustal detachment model. The early Mesozoic basins of the eastern North America, believed to have formed as the result of the normal-slip reactivation of a Paleozoic thrust system as the Atlantic opened, are associated with distinctive hanging wall gravity highs. These gravity highs, the basin geometry, the lack of a thermal subsidence phase in the rift basins, and the presence of a highly extended and heated region to the east, suggest that the simple shear model may be
\end{abstract}

\footnotetext{
${ }^{1}$ Also at Department of Geological Sciences, Columbia University, New York.

Published in 1988

by the American Geophysical Union.
}

Paper number 8T0115.

0278/7407/88/008T-0115\$10.00 applied. The simple shear model fits the outer hanging wall anomaly and permits a region of lower crustal extension to be mapped. These basins contain an abundance of basalt flows and diabase sills despite the lack of evidence for regional heating or thermal subsidence, implying that a source, external to the basin, must exist for this magmatic material. The detachment fault may facilitate the movement of the molten mafic material into the rift basins from an offshore region of greater heating and extension. The addition of $2 \mathrm{~km}$ of mafic material along the model detachment accounts for the observed inner gravity high and the lack of a negative gravity anomaly across these basins. The match of this modified simple shear model to the observed gravity suggests that the region of greater extension seaward of the hinge zone is the source for the widespread dikes and sills within the basins and the coastal plain and helps explain the geochemical homogeneity of these intrusives and extrusives along $2000 \mathrm{~km}$ of the eastern seaboard.

\section{INTRODUCTION}

In recent years there have been great advances in our understanding of lithospheric rifting. Analysis of basin subsidence has revealed a major thermal contribution to the postrift subsidence of large extensional basins and passive margins [Sleep, 1971; Steckler and Watts, 1978]. Conceptual models [e.g., McKenzie, 1978] helped to define a relationship between lithospheric extension and the heating and crustal thinning in passive rifts, allowing quantitative estimates of verti- 
cal motions to be made. The recognition of lowangle normal faults by surface mapping has added a new dimension to our understanding of how the upper crust extends [Wernicke and Burchfiel, 1982; Wernicke, 1985]. Information on crustal extension has generally come from seismic refraction and reflection profiling. In particular, seismic data has: (1) imaged the thinning of the crust under some basins and passive margins [e.g., Barton, 1986; Large Aperture Seismic Experiment (LASE), 1986], (2) demonstrated the importance of detachments in localizing extension, and (3) shown that small rift basins form within the collapsed hanging wall of normally reactivated thrusts [British Institutes Reflection Profiling Syndicate (BIRPS) and Etude de la Croûte Continentale et Océanique par Réflexion et Réfraction Sismique (ECORS), 1986]. Although these observations document the existence of thin crust beneath extended regions and the complex geometry of extension, they do not address the process by which the thinning occurs [Allmendinger et al., 1987].

Direct knowledge of the process of lithospheric extension remains restricted to observations of the upper crust. Evidence for deep-level extension comes primarily from seismic activity within rift zones and the exposure of exhumed detachment surfaces, but the actual distribution of extension with depth, and the role of detachments, is poorly constrained. It is these detachments that transmit surface extension down to mid crustal and lower crustal levels. Whatever the role of these detachments is in laterally transmitting strain, the amount of extension observed at the surface of a rift must be balanced by an equal amount of extension at depth [Kligfield et al., 1984].

There are two important models for the distribution of extension at depth beneath rifts. The simplest and most commonly assumed model is that of uniform, symmetric lithospheric extension [McKenzie, 1978]. This model assumes that the lithosphere fails by depth-independent pure shear. Numerous variations on this theme have been proposed for the distribution of extension with depth [Royden and Keen, 1980; Hellinger and Sclater, 1983; Rowley and Sahagian, 1986]. These models generally assume that although the distribution of extension varies with depth, it remains centered beneath the rift. A radically different model is that of uniform sense simple shear throughout the lithosphere [Wernicke, 1985; Lister et al., 1986]. With this proposed geometry, detachments continue throughout the entire lithosphere. As a result, the extension and upwelling at depth is asymmetrically distributed with respect to the rift. Asymmetric extension, as implied by the presence of detachments, should produce different vertical motions of the lithosphere than that of uniform extension. To understand these vertical motions, we need to determine the isostatic response of the lithosphere during rifting, a process that is not well understood. Virtually all investigators have assumed local isostasy during rifting [McKenzie, 1978; Steckler and Watts, 1978, 1980; Royden and Keen, 1980; Sclater and Christie, 1980; Watts et al., 1982; Beaumont et al., 1982 ].

The state of isostasy plays a critical role in determining the effect of detachments during extension. Our current understanding of isostasy during rifting has come principally from continental margins, large intracratonic basins and major rift zones. In all of these cases, a large thermal perturbation is introduced into the lithosphere, resulting in isostatic uplift. The thermal input not only produces a time-varying uplift but also progressively modifies the flexural rigidity. Consequently, this paper will focus on basins with only minor, local thermal perturbations in order to document the effects of flexure during rifting. Such basins exist where the presence of detachments indicate that heating is laterally displaced relative to the rift, thereby isolating the upper crustal response. Our objective is to develop two end-member rifting models to compare with known examples of thermally "isolated" basins and to investigate the distribution of strain through the crust, particularly in the lower crustal regions. The purpose of this paper is to investigate the isostatic state of thermally isolated basins during rifting, the distribution of strain in the lower crust, and the role of detachments in the development of basins. We particularly investigate the Mesozoic aged basins of eastern North America.

\section{MODELING ASYMMETRIC EXTENSION}

It has been over 30 years since Vening Meinesz first described the flexural effects across the Rhine and African rifts, which imply a nonlocal isostatic response of the lithosphere to extension [Vening Meinesz, 1950; Heiskanen and Vening Meinesz, 1958]. The African rift lakes are characteristically half graben, associated with prominent footwall uplift with a magnitude directly proportional to the basin subsidence [B. Rosendahl, personal communication, 1986]. This uplift is difficult to explain as a thermal effect because of its asymmetric nature and the frequency with which it alternates between sides of the lake. Footwall uplift requires flexural strength of the lithosphere during rifting.

Vening Meinesz' original analysis assumed: (1) the existence of normal planar faults which fracture the entire crust (and by inference the elastic lithosphere), and (2) once the crust is broken, it acts as a pair of independent cantilever beams 
separated by the fault. The unloading and loading of the crust on either side of the fault is therefore considered independently. Because of this extreme assumption, lower plate (footwall) uplift and upper plate (hanging wall) subsidence are maximized. The main control on the uplift and subsidence wavelength is the flexural rigidity of the upper and lower plates. Increasing fault dip tends to decrease the footwall block uplift, a vertical fault dip yielding no uplift.

This classical analysis of normal faulting and footwall uplift fails to adequately consider: (1) the possible mechanical interaction of the uplifting lower plate and subsiding upper plate, which may significantly reduce the deformation of both blocks, (2) that breaking the crust does not necessarily imply flexural failure of the whole lithosphere, and (3) that crustal extension is often characterized by the utilization of low-angle intracrustal detachments, which show a general listric nature, rather than high-angle normal faults. These points must be addressed before a realistic assessment can be made of the importance of flexure and isostasy during rifting.

Zandt and Owens [1980] attempted to correct for the second of these deficiencies. They considered complete decoupling and continuity across the fault as two possible end members. Jackson and McKenzie [1983] extended Vening Meinesz' formulation by including vertical forces exerted by the upper and lower plate on each other. Because the forces were not specified, they could only estimate the ratio of footwall uplift to hanging wall subsidence and not the actual magnitudes. Jackson and McKenzie, as Vening Meinesz, resolved these forces onto a vertical plane as end-loading forces on a cantilever beam. The mismatch of the bending in the overlapping parts of the footwall and hanging wall was still not considered.

To address all three of the problems associated with the original Vening Meinesz approach, we view extension along low-angle faults as a unloading process, i.e., the rebound associated with the negative load of the hole produced by the movement of the hanging wall block along a listric fault. In the example given (Figure 1) the shape of the hole is generated by the mechanical collapse of the hanging wall by a series of vertical faults [Gibbs, 1984; Bosworth et al., 1986]. Other styles of upper plate fragmentation may be considered [e.g., McClay, 1987] by adjusting the shape of the upper plate. The heave, or horizontal movement along the fault, is $10 \mathrm{~km}$ in this case. The final predicted topography will be the sum of the flexural response to upper plate unloading, with the shape of the hole controlled by mechanical failure of the hanging wall block.

For simplicity we have assumed that the
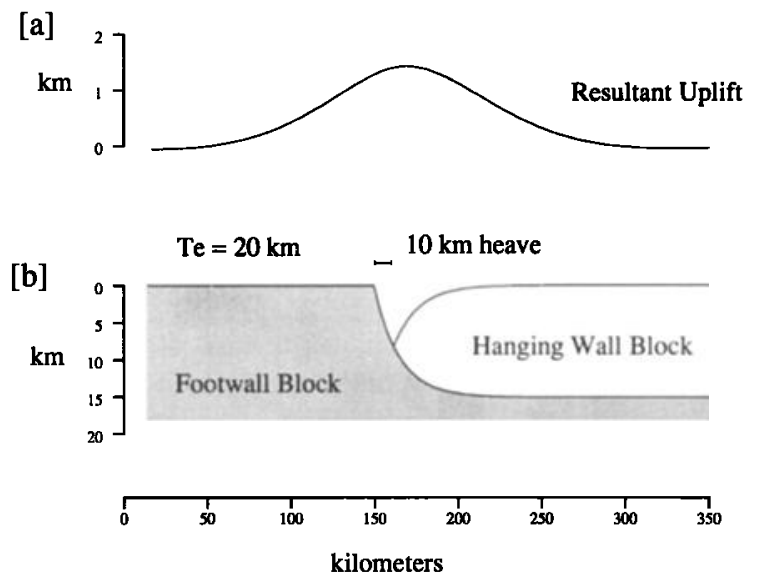

Fig. 1. (a) Illustration of the isostatic adjustments of the lithosphere to extension along a listric detachment. Net isostatic rebound caused by the extension for a $T_{e}=20 \mathrm{~km}$ and heave (total horizontal extension) of $10 \mathrm{~km}$. Uplift is induced in both the footwall and hanging wall block. (b) Crustal structure after extension has occurred along the fault, and the hanging wall block has collapsed but before the system responds to the hole. Shape of upper plate results from failure along vertical faults.

flexural rigidity across the fault zone can be approximated by a continuous elastic plate with constant flexural rigidity overlying a weak fluid (the flexural ridigity is expressed in terms of $T_{e}$, the effective elastic thickness of the lithosphere, and reflects the integrated rheological properties of the lithosphere). The example given uses a $T_{e}$ of $20 \mathrm{~km}$. Other assumptions for the flexural rigidity across a fault zone include a reduction of the elastic thickness by the thickness of the upper plate (if the upper plate is fragmented), or if the upper plate has strength, an effective rigidity corresponding to a leaf spring combination of the rigidities of the upper and lower plates, i.e., geometric mean. We have found that the difference between these assumptions is important only when the elastic thickness of the lower plate becomes small or when the detachment approaches the base of the elastic lithosphere.

Isostatic uplift, in addition to producing the well-known footwall uplift, also produces uplift of the hanging wall block. This uplift must deform the detachment surface. The typical abandonment of the breakaway zone and exposure of the detachment at the surface by antiformal uplift [Wernicke, 1981; Spencer, 1984] may be, in part, a natural consequence of lithospheric strength during extension [W. R. Buck, Flexural rotation of normal faults, submitted to Tectonics, 1988]. A detachment surface is first locked by hanging wall uplift, 

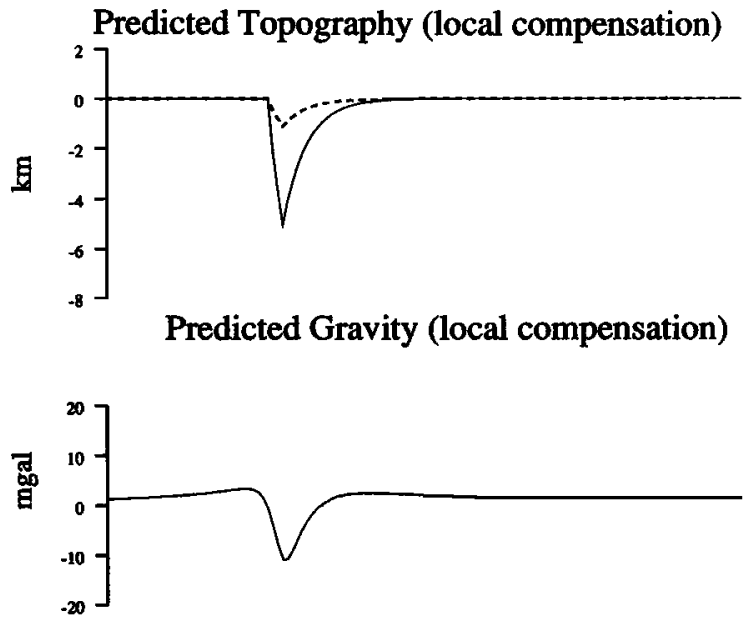

Predicted Topography $\mathrm{Te}=30 \mathrm{~km}$

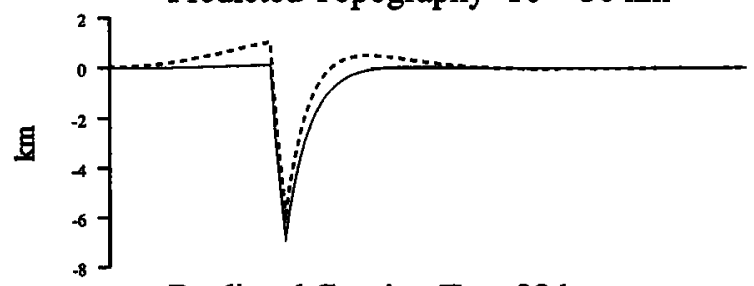

Predicted Gravity $\mathrm{Te}=30 \mathrm{~km}$
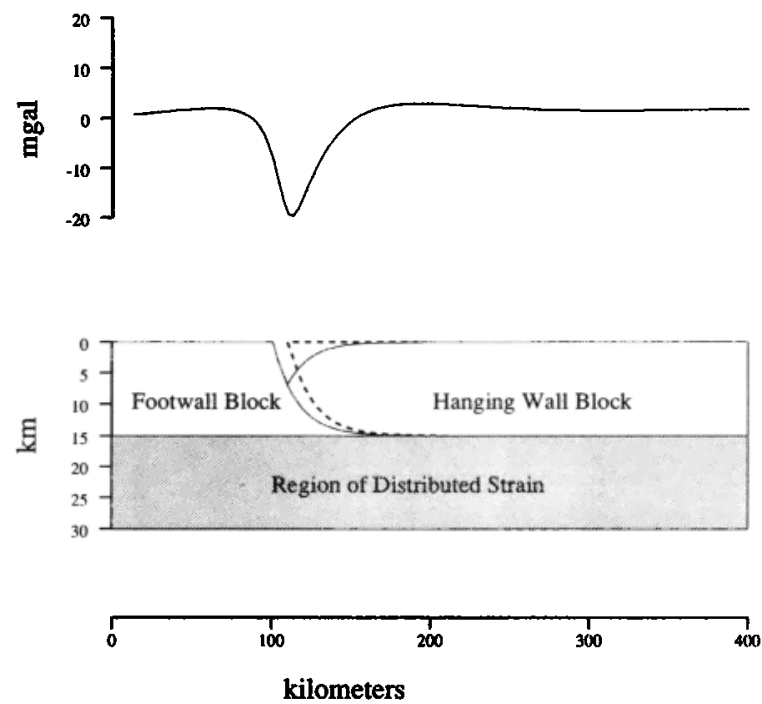

Fig. 2. Results of extension of the crust involving an intracrustal detachment for both local and flexural isostasy. In the upper crust, extension is accommodated along a listric fault, while in the lower crust the same amount of extension is accommodated in a zone of distributed strain (shaded). The predicted topography includes results for a sediment-starved (dashed line) and sediment-filled basin (solid line). The gravity was calculated for a sediment-filled basin. The flexural results were calculated with $T_{e}=30 \mathrm{~km}$ while the locally compensated calculations are equivalent to $\mathrm{T}_{\mathrm{e}}=0 \mathrm{~km}$. and then, following the formation of a new breakaway zone, exposed by subsequent footwall uplift.

\section{TWO ASYMMETRIC EXTENSION MODELS INCORPORATING FLEXURE}

In order to estimate the effects of flexure during rifting we consider two end-member extension models where the upper crustal rifting does not overlie a local thermal anomaly (Figures 2 and 3). The first examines the isostatic response to extension across an upper crustal, listric fault which flattens into a zone of distributed strain in the lower crust (Figure 2). The thermal uplift associated with this model will have a relatively long wavelength. With this broad thermal uplift, the localized flexural upwarping at the surface rift can be easily recognized and separated. The entire region encompassing the rift will have an elevated heat flow, and the observed flexural rigidity will be reduced.

The second model examines the isostatic response of simple shear extension, in which a single narrow zone of failure cuts through the entire crust and lithosphere (Figure 3). In this model the mechanical and flexural behavior of the upper crust is spatially isolated from the thermal effects due to the asymmetry of the extension.

These two models represent end-member cases, and most actual rifts probably incorporate elements of both models. Zones of failure, for instance, commonly are localized near the surface and become broader and more diffuse with depth as the failure mechanism changes from brittle faulting to ductile creep. Settings in which basins similar to our end-member models might occur are extension in exceedingly thick, hot, and therefore weak crust, e.g., Tibetan Plateau, or normally reactivated thrust faults with relatively small amounts of extension, e.g., Wessex Basin, southern England.

The resultant patterns of uplift, subsidence, and gravity anomalies for the two models are illustrated in Figures 2 and 3. We have calculated the results for both flexural and local compensation schemes. Local compensation produces no footwall or hanging wall uplift, and the predicted basin is shallower than for a flexurally compensated basin produced by the same amount of extension. The locally compensated simple shear model develops a second basin directly over the region of concentrated strain in the lower crust, which is identical to the main rift basin. Both locally compensated models are characterized by a 15-mGal low centered over the main rift basin. A similar amplitude gravity low is associated with the second basin in the locally compensated simple shear model. 


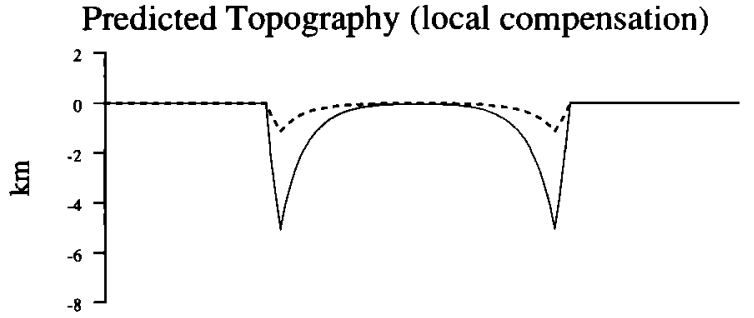

Predicted Gravity (local compensation)

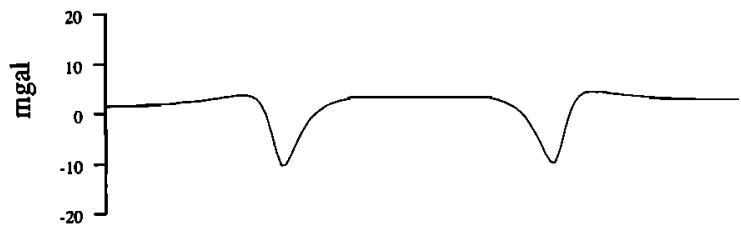

Predicted Topography $\mathrm{Te}=30 \mathrm{~km}$

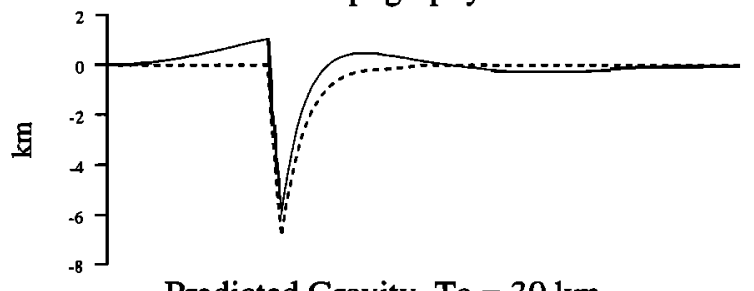

Predicted Gravity $\mathrm{Te}=30 \mathrm{~km}$
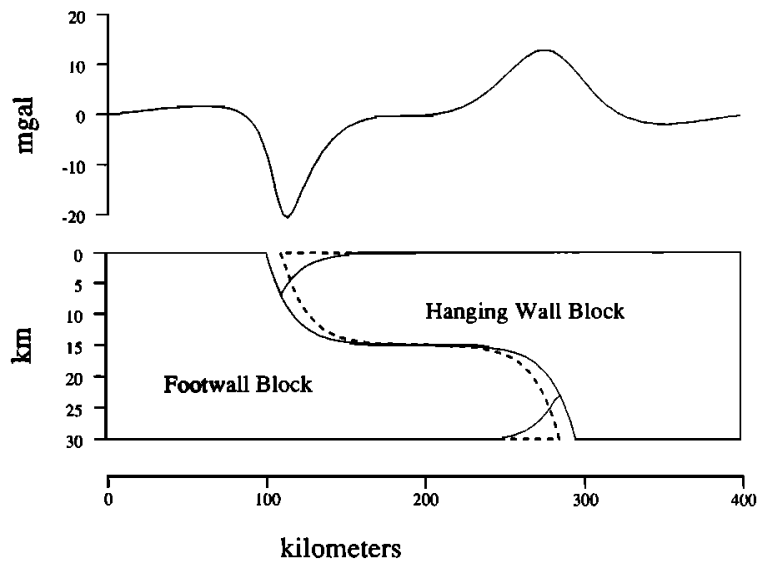

Fig. 3. Results of crustal extension involving a through-going simple shear detachment for both local and flexural isostasy. In the lower cross section the dashed line indicates the position of the plates after extension but before collapse of the blocks (solid line). The amount of extension is the same (heave of $10 \mathrm{~km}$ ) as presented for the intracrustal detachment model in Figure 2. The predicted topography includes the predicted vertical motions for a sediment-starved (dashed line) and a sediment-filled basin (solid line). The gravity was calculated for a sediment-filled basin. Note the development of a sag basin within the hanging wall block and its associated hanging wall gravity high for the flexural isostasy case. The flexural results were calculated with $\mathrm{T}_{\mathrm{e}}=30 \mathrm{~km}$ while the locally compensated results are equivalent to a $\mathrm{T}_{\mathrm{e}}=0 \mathrm{~km}$.
Both models with flexural compensation produce footwall uplift, an asymmetric basin, and a topographic bulge on the hanging wall side. The footwall uplift, for an elastic thickness of $20 \mathrm{~km}$, a $10-\mathrm{km}$ heave along the fault and a sediment starved basin, is about $1 \mathrm{~km}$. The hanging wall block uplift is $300 \mathrm{~m}$. However, both uplifts are greatly decreased by sediment loading. The gravity signature associated with these models primarily reflects the sum of density contrasts across the sediment-crust interface and the crust-mantle interface.

The two flexural extensional models (Figures 2 and 3) are distinguished by several predictions. For example the intracrustal detachment model is characterized by a broad uplift due to the zone of distributed strain in the lower crust and mantle and a similar shift in the gravity level. Depending on the breadth of the zone of distributed strain, these features may or may not be easily detectable. In contrast the simple shear model develops a positive load due to crustal material being replaced by mantle material where the detachment cuts through the crust. The flexural response of the lithosphere to the narrow zone of deep crustal thinning is the formation of a broad sag basin. The gravity anomaly produced by this deep crustal thinning critically depends on the amount of sediment fill within this basin. If the sag basin is sediment starved, the gravity signal over the basin is dominated by the surface interface and is a broad low. Filling the sag basin with sediment results in a distinctive $15-\mathrm{mGal}$ high directly centered over the region of deep crustal thinning. This gravity high on the hanging wall block is an important indicator of the the actual location of the region of subcrustal thinning. However, the gravity signature is quite insensitive to the actual shape of the thinned region. For a constant amount of extension increasing the lateral extent of the thinned lower crust will decrease the amplitude of the hanging wall gravity high slightly. Doubling the lateral extent of this extended region reduces the anomaly produced by $1-2 \mathrm{mGal}$.

A number of factors control the amplitude and the shape of the uplift for the flexural models. Filling the half graben with sediment will dampen the uplift across the entire system. The dip of the fault is critical in controlling the resultant topography. Given a constant flexural strength and heave, a through-cutting planar fault with no midcrustal detachment produces decreasing deflections as the fault steepens [Vening Meinesz, 1950; Jackson and McKenzie, 1983]. This contrasts with the results presented here for a fault intersecting a horizontal detachment at midcrustal levels where a steeper fault will produce greater uplift and a narrower, deeper basin. In Figure 1 and all subsequent models we have used a listric-shaped fault soling into a horizontal detachment at midcrustal levels. The listric shape has little influence on our 
results as a planar fault soling into a detachment, as suggested by Eyidogan and Jackson [1985], produces very similar results. The depth of the intracrustal detachment is positively correlated to the amount of uplift. A deeper detachment level, for a given set of parameters, will displace a greater amount of crust, produce a larger hole and consequently greater uplift. As the elastic strength of the lithosphere increases, the amplitude of the uplift produced decreases while the area uplifted becomes broader. Simultaneously, the main basin becomes narrower and the sag basin over the region of subcrustal extension becomes less distinct.

Although the results are dramatically different for flexural versus local compensation (Figures 2 and 3 ), the models are relatively insensitive to variations in $\mathrm{T}_{e}$; changes in predicted uplift are similar in amplitude to the uncertainties in prerift topography. Other indicators, such as the increase in the size of the hanging wall high for the simple shear model (Figure 3) are problematic because the region of concentrated extension is generally poorly constrained. Changing the distribution of extension in the lower crust produces shifts in the gravity field similar to those resulting from variations in $T_{e}$. Although these models can be used to identify the existence of lithospheric strength, i.e., flexural versus local compensation, the number of poorly constrained variables makes the accurate determination of $T_{e}$ during rifting difficult.

\section{EXAMPLES OF ASYMMETRIC RIFT BASINS}

\section{Early Mesozoic Basins of Eastern} North America

Extension within old collisional belts is often characterized by the normal reactivation of large thrust faults [BIRPS and ECORS, 1986; Lake and Karner, 1987]. Such reactivations within an extensional tectonic setting may produce a rift geometry similar to that of our simple shear model (Figure 3). The early Mesozoic rift system along the east coast of North America consists of a series of half graben believed to represent the first phase of extension which opened the central North Atlantic. These half grabens appear to exist within the collapsed hanging wall of normally reactived Paleozoic thrust faults [Ratcliffe and Burton, 1985; Swanson, 1986]. This rift system, containing the sediments of the Newark Supergroup [Froelich and Olsen, 1984], consists of more than 20 basins along the eastern seaboard, some exposed at the surface, such as the Fundy, Hartford, Culpeper and Newark basins, and others covered by coastal plain sediments, such as the Riddleville Basin and the Long Island Platform basins [Peterson et al., 1984; Hutchinson et al., 1986; Klitgord and Behrendt, 1979].
Evidence for the reactivation of ancient thrust faults during the formation of these Mesozoic rift basins comes from both structural geology and seismic reflection data. The structural fabrics within the mylonites along the Musconetcong thrust system, close to the border fault of the Newark Basin, record an extensional overprint [Ratcliffe et al., 1986]. This thrust system has been traversed by seismic reflection lines and drilled in a series of boreholes [Ratcliffe et al, 1986; Ratcliffe and Costain, 1985]. The seismic reflection studies indicate that the Musconetong thrust system is subparallel to the border fault of the Newark Basin, suggesting that the basin geometry was controlled by preexisting structures.

The basins represent the preserved western limit of Mesozoic rifting. Reconstructions of the initial rift configuration indicate that extension took place over an extremely broad area during the early stages of rifting. The most highly extended and heated lithosphere lies seaward of the hinge zone, which marks the westernmost limit of the highly stretched crust which produced the passive margin sequence, as evidenced by the distribution of postrift sedimentation and the location of maximum crustal thinning [Watts and Steckler, 1979; LASE, 1986]. Geochemical evidence suggests that a maximum sediment thickness of $2 \mathrm{~km}$ has been removed from these basins [Pratt et al., 1985; Katz et al., 1988]. This lack of a thick postrift sediment cover over the Mesozoic basins and their peripheral position to the continental margin suggests that they were never greatly heated. The presence of upper crustal extension with no appreciable local thermal subsidence implies that the near-surface extension within these basins was probably accommodated at depth by extension closer to the main offshore rift basins. The geometry of these basins therefore appears similar to the extensional style described by our simple shear model (Figure 3).

A number of the Mesozoic half grabens are associated with a distinctive 15 - to 25 -mGal gravity anomaly high over the hanging wall block. These highs, frequently local culminations superimposed on the Appalachian gravity high, are associated with the Newark, Gettysburg, Culpeper and Riddleville basins (Figures 4 and 6). This gravity high is absent in regions where no basin exists, as is the case south of the Culpeper basin. Further, these basins and the associated gravity highs cut across the structural trend of the Appalachians and the trend of the Appalachian gravity high. This cross-cutting relationship is important, as it implies that the gravity high must be associated with the basin-forming process and is not simply the result of preexisting crustal inhomogeneities.

To highlight the Mesozoic basin gravity anomalies and associated hanging wall highs, the 


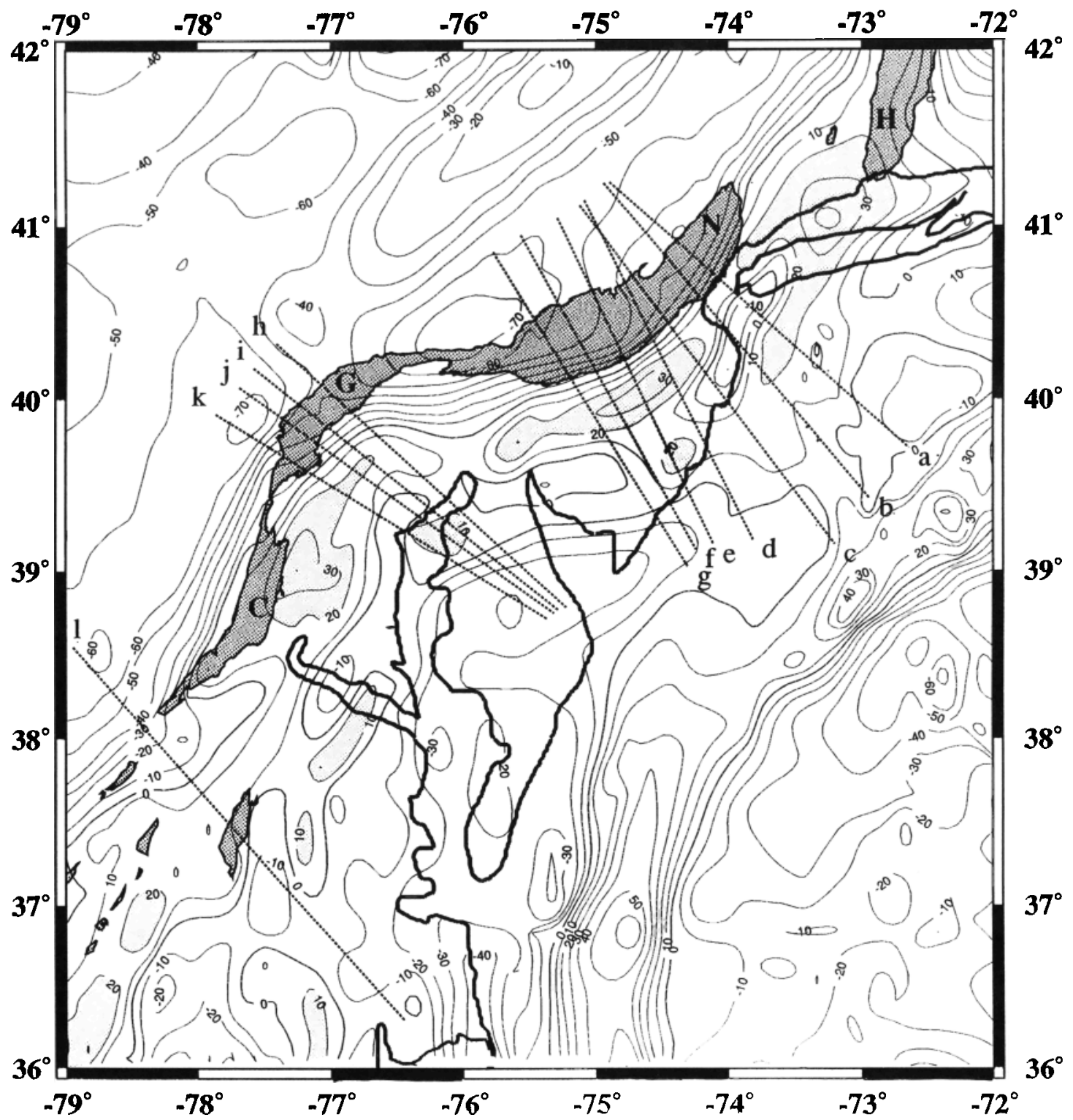

Fig. 4. Bouguer gravity map of the mid-Atlantic region of the U.S. east coast. The dark shading indicates the location of the Mesozoic basins (N, Newark; G, Gettysburg; C, Culpeper; $\mathrm{H}$, Hartford). The light shading pattern indicates the gravity highs on the hanging wall side of the basins. The dashed lines are the locations of the profiles used in this study.

Appalachian gravity high must be removed. The Appalachian gravity high is associated with the deep crustal structure formed during the collisional events of the Taconic and Acadian orogenies from the Ordovician through the Carboniferous [Karner and Watts, 1983; Cook 1984]. To remove the effects of this preexisting structure from the signature of the Mesozoic basins, we have treated the profiles (locations shown in Figure 4) with a Gaussian filter that removes wavelengths greater than $200 \mathrm{~km}$. Where no basin is associated with the Appalachian gravity high, no distinct high remains after the filtering process substantiating our filtering procedure (Figure 5).

Several distinctive features appear in the filtered gravity profiles shown in Figure 6. The first are the gravity highs over the hanging wall blocks that were also apparent in the map view (Figure 4). Almost all the profiles have a shortwavelength $(50 \mathrm{~km}), 25-\mathrm{mGal}$ high just to the east of the basin edge (inner gravity high), and most also have a second gravity high further to the east 

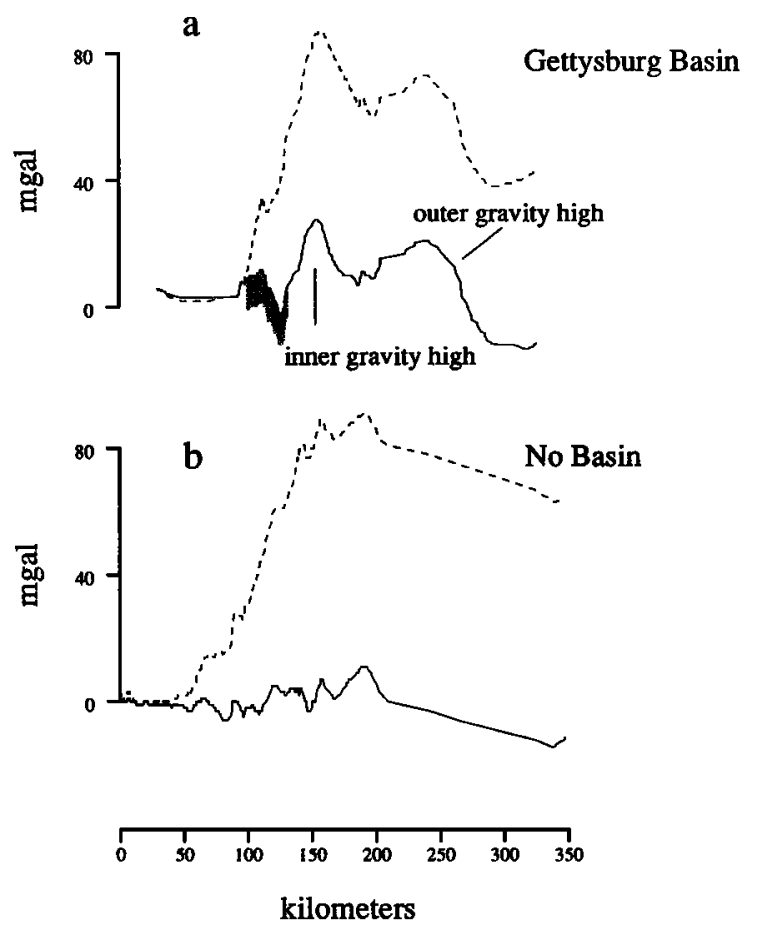

Fig. 5. (a) Observed (dotted) and filtered (solid) profiles across the the Gettysburg Basin (profile $j$, Figure 4). Shading shows present exposure of the basin. (b) Observed (dotted) and filtered (solid) profiles across the Appalachian gravity high south of the Culpeper Basin where no basin is closely associated with the Appalachian gravity high (profile 1, Figure 4).

(outer gravity high). The outer gravity high, seen distinctly in profiles $a, c, j$, and $k$ (Figure 6 ) has an amplitude of $20-\mathrm{mGal}$ (similar to the inner gravity high), is slightly broader (up to $100 \mathrm{~km}$ wide), and sometimes appears to merge into the inner gravity high. The merging of these two highs produces either a broad double-peaked high as seen in the Central Gettysburg (profile h) or a single high as in the Southern Newark (profiles $f$ and $\mathrm{g}$ ). The second interesting feature of these basins is the lack of a large gravity low associated with the sedimentary infill. The gravity low over the basin reaches a minimum of $-8 \mathrm{mGal}$ over the Newark and $-10 \mathrm{mGal}$ over the Gettysburg. In some cases, such as profiles $f$ and $g$, there is no low over the basin.

As no evidence remains of the uplift history of these basins, the gravity anomalies are the only key to the isostatic state of the basins during rifting. All the models, regardless of detachment geometry or isostatic state, predict a large 15- to 20 -mGal low centered over the rift basin. The distinctive hanging wall gravity high is the discriminating feature for the models. Neither the intracrustal detachment model nor the locally compensated simple shear model produces a hanging wall gravity high. In fact, the latter model produces a large gravity low over the secondary basin. The only model which appears to match the gravity anomaly across these basins is the flexurally compensated simple shear model (Figure 3). This model also closely correlates with the asymmetric geometry inferred from the reactivation of the Mustconetcong thrust system.

Our modeling of these basins is constrained by the basin depth and width, the density of the infill, the surface dip of the border fault, and the gravity anomaly. The modeling results presented incorporate a $10-\mathrm{km}$ heave along the border fault which produces a standard basin, $45 \mathrm{~km}$ wide and $6 \mathrm{~km}$ deep, approximately the mean size of the Newark and Gettysburg basins. The basin infill for the models is a weighted average of the basalt density $\left(2.9-3.1 \mathrm{~g} / \mathrm{cm}^{3}\right)$ and the sediments $\left(2.4-2.7 \mathrm{~g} / \mathrm{cm}^{3}\right.$; [Sumner, 1977]) based upon their relative abundance and location in the section. The density of the surrounding crustal rocks varies from 2.6 to $3.0 \mathrm{~g} / \mathrm{cm}^{3}$. Densities of $2.6 \mathrm{~g} / \mathrm{cm}^{3}$ for the surface rocks and $3.3 \mathrm{~g} / \mathrm{cm}^{3}$ for the mantle were used. The border fault dip along the Newark basin ranges from $70^{\circ}$ in the north to $30^{\circ}$ in the south [Ratcliffe and Burton, 1985]. The model border fault is defined as a curve whose dip decays exponentially with depth. All the models use a fault with a surface dip of $45^{\circ}$ and an exponential decay of 15 km.

The remaining free parameters are the strength of the lithosphere $\left(\mathrm{T}_{e}\right)$ and the location of the region of lower crustal extension. As noted above, the lithospheric strength primarily controls the development of a sag basin and the amplitude of the gravity anomaly over the region of subcrustal thinning. Any sag basin developed with these Mesozoic basins is now covered by coastal plain sediments. Thus the gravity signature is the only remaining indicator of $\mathrm{T}_{e}$ during rifting. Assuming that the lower crustal extension mirrors the upper crust extension, the amplitude of the outer hanging wall gravity anomaly is best fit by $a T_{e}$ of $30 \mathrm{~km}$.

The gravity signature of the model is most sensitive to the location of the region of lower crustal extension. Concentrating the lower crust extension in a narrow region similar in shape to the basin produces a $20-\mathrm{mGal}, 120 \mathrm{~km}$ wide gravity high. Figure 7 shows the gravity anomaly produced by varying the distance from the surface fault to the subsurface region of extension $\left(D_{L}\right)$ from 50 to $200 \mathrm{~km}$ in $50-\mathrm{km}$ increments. At 200 $\mathrm{km}$ the subcrustal anomaly is distinct from the basin anomaly while at $50 \mathrm{~km}$ the amplitude of the subcrustal anomaly almost completely cancels the basin low. 
Newark

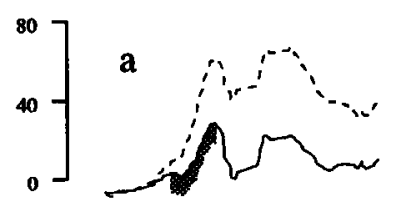

\section{Gettysburg}
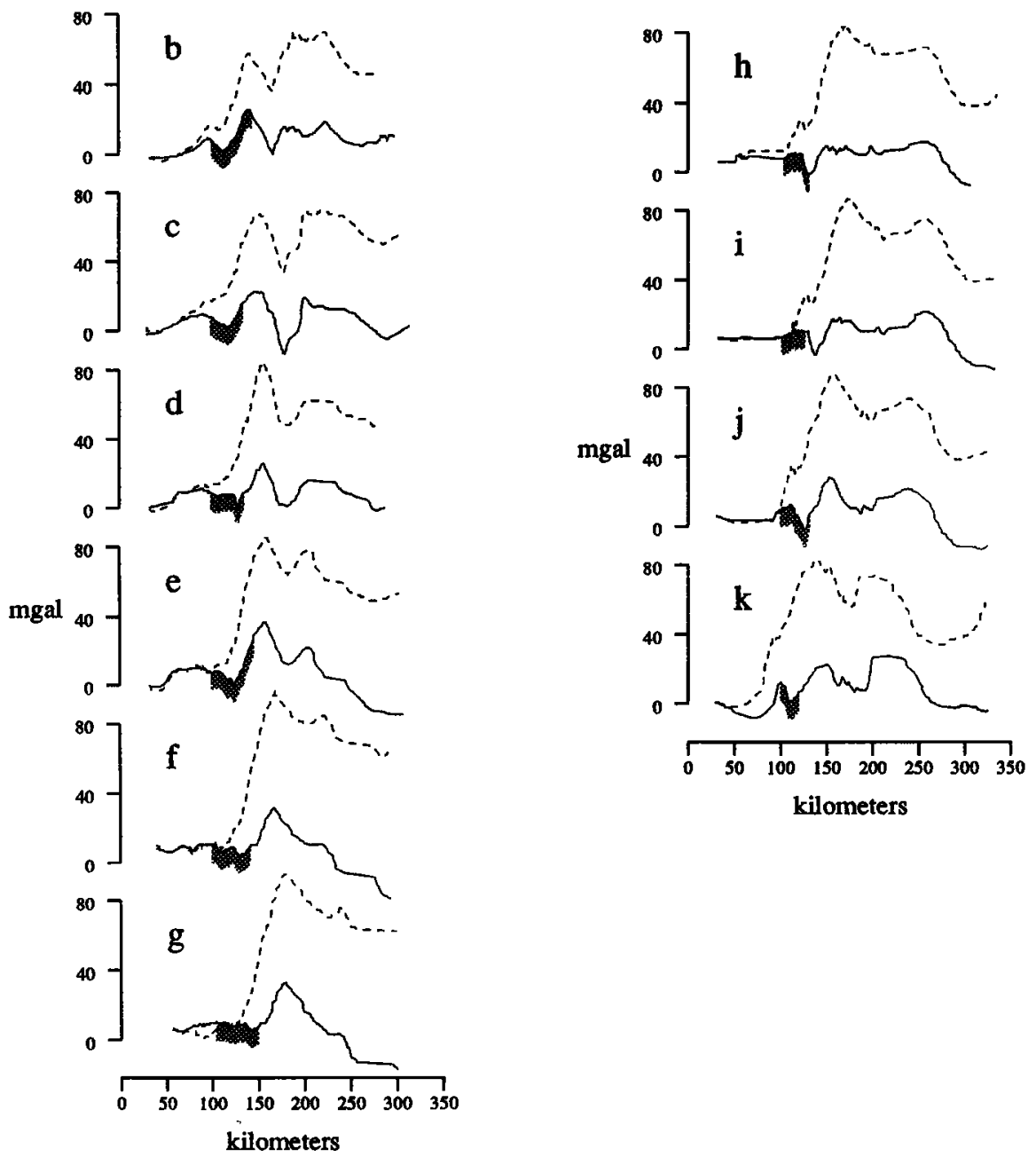

Fig. 6. Raw Bouguer gravity profiles (dashed lines) across the Newark and Gettysburg basins superimposed on the filtered profiles (solid lines). The location of these profiles is found in Figure 4. The shading indicates the present surface exposure of the basins.

The predictions of the simple shear model for a $T_{e}$ of $30 \mathrm{~km}$ and a heave of $10 \mathrm{~km}$ are shown in Figure 8 overlaying the profiles from the Newark and Gettysburg basins. Only the distance from the border fault to the region of concentrated subsurface extension $\left(D_{L}\right)$ was allowed to vary. To fit the data, values from $100 \mathrm{~km}$ in the southern Newark basin to $170 \mathrm{~km}$ in the northern Gettysburg basin were needed. The wavelength and the amplitude of the outer gravity high closely matches the model for the majority of the profiles. A consistent discrepency between the model and the observed gravity profiles exists across the basins and the inner gravity high. The model fails to account for some excess mass beneath the basin and the proximal hanging wall.

The goodness of fit for the outer hanging wall anomaly varies along the basin. The predicted anomalies fit best in the northern Newark basin (profiles $a-d$ ) and in the Gettysburg basins. The 

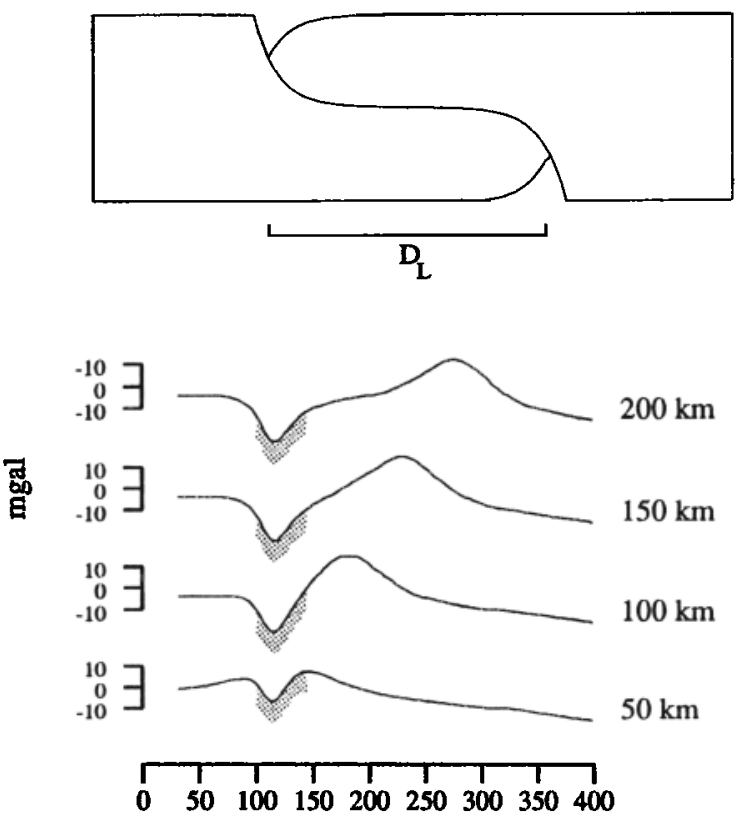

\section{kilometers}

Fig. 7. Predicted gravity for the simple shear detachment model allowing the distance from the border fault to the region of subcrustal extension $\left(D_{L}\right)$ to vary from 200 to $50 \mathrm{~km}$ from the border fault. The shading represents the extent of the predicted basin.

deterioration of the fit in the other areas probably reflects the important control the border fault dip has on the resulting basin anomaly. As noted above, the dip of the Newark basin border fault decreases from a maximum of $70^{\circ}$ in the north to $30^{\circ}$ in the south. The three Newark basin profiles which closely match the modeled anomaly are those where the border fault has a measured dip of $45^{\circ}$. The models presented in Figure 8 incorporate a detachment with a surface dip of $45^{\circ}$ and an exponential decay of $15 \mathrm{~km}$.

For a given set of parameters the location of the region of lower crustal extension is the variable which is best constrained by these models. The results from the Newark and Gettysburg basins imply that this region is further to the east of the Gettysburg basin than the Newark basin. The model predicts maximum ranges of $150-170$ $\mathrm{km}$ to the east of the border fault for the Gettysburg basin and $100-150 \mathrm{~km}$ to the east for the Newark. The hinge zone is $110-160 \mathrm{~km}$ east of the Newark basin border fault while it is $230 \mathrm{~km}$ east of the Gettysburg basin. The results of the modeling correlate broadly with previously mapped limits of stretching [Watts and Steckler, 1979].
In conclusion we have found that the Mesozoic basins of eastern North America have distinctive gravity highs over the hanging wall block. This outer gravity high can be modeled by the density contrasts along a detachment which cuts through the entire crust (Figure 3). A detachment which soles at midcrustal levels above a region of broadly distributed strain does not produce a hanging wall gravity high and cannot be used to explain the gravity anomaly across the Newark and Gettysburg basins. The lithosphere must have strength during the rifting process to produce this gravity high. The outer gravity high can be used to trace the location of the extension within the lower crust. This region of concentrated extension generally corresponds to the highly stretched crust beneath the continental margin.

\section{Role of Detachments as Magma Conduits}

Although the simple shear model with flexural compensation (Figure 3) sucessfully predicts the outer gravity high, we fail to predict the gravity signature across the basin and the inner gravity high. The close proximity of the basins to the inner gravity high implies that a single density contrast can explain both the basin and inner hanging wall gravity signatures. A number of possible explanations could be proposed for the absence of a large low across the basins. One explanation is that the basement geometry is more complex than a simple half graben bounded by a single border fault. A more complicated fault geometry could easily rotate blocks of relatively high-density basement close to the surface as is seen in modern extensional enviroments such as the Gulf of Suez. This may be the case in the southern Newark basin (Figure 8, profile f) where a basement block is exposed in the center of the basin but seems less likely in the northern Newark where no evidence for major faulting within the basin is found. A second explanation for the lack of a gravity anomaly within the basins could be high density tholeiitic dykes and sills. After the regional gradient is removed, local gravity highs of 5-11 mGal occur over the surface exposure of the sills in the southern Newark basin [Sumner, 1977]. Profiles $f$ and $g$ (Figure 8) both cross sills which may explain the lack of a negative anomaly across the basins. Neither of these explanations satisfactorally accounts for the small anomalies across the northern Newark basin and the Gettysburg basin where no dense material is exposed at the surface. A third solution is to fill the basin with large amounts of diabase, decreasing the average density contrast between the basin infill and the surrounding crustal material. This alternative requires more than double the presently mapped occurrence of igneous material to elevate 

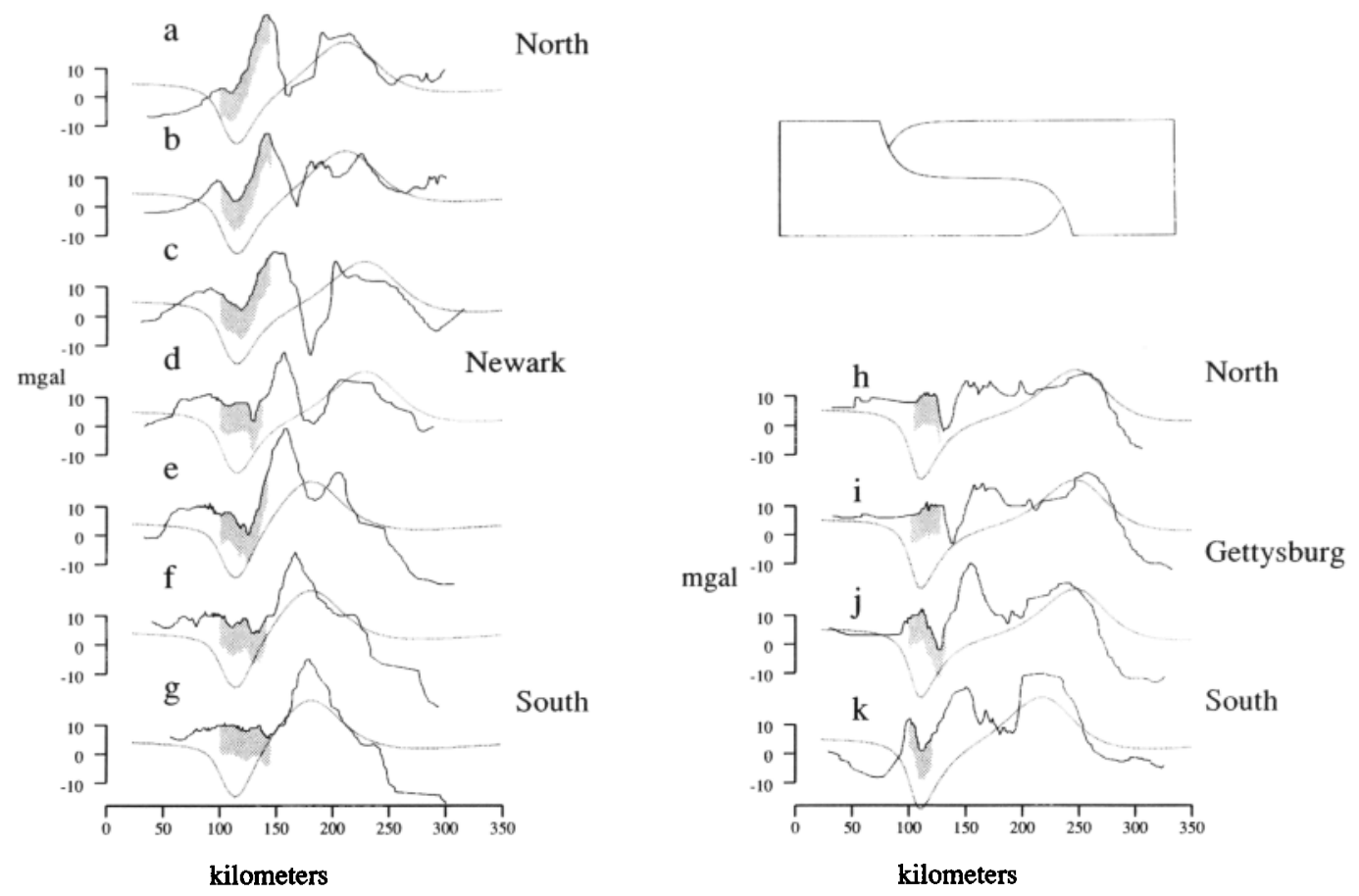

Fig. 8. Results for a simple shear detachment model (dashed lines) superimposed upon the filtered profiles (solid lines) across the Newark series basins. The distance from the border fault to the region of subcrustal extension $\left(D_{L}\right)$ was allowed to vary.

the infill density sufficiently. No evidence for this amount of diabase material has been detected within these basins. As it is difficult to explain this gravity high with any known density contrasts within the basin, it must result from a density contrast within the hanging wall block, probably related to the basin-forming process.

This failure of the model to explain the gravity high over the basin and the proximal hanging wall block implies that a mass excess must exist for the entire region. This mass excess could be caused by preexisting crustal inhomogeneities such as a suite of ophiolitic slivers. Small pieces of ultramafic material, such as the Staten Island ophiolite, have been identified within the hanging wall block. As these ultramafic bodies have a very limited distribution and are often associated with gravity lows, they cannot account for the gravity positive across the hanging wall.

It is clear that the gravity anomaly across these basins requires a large high-density body beneath the basin and the inner hanging wall. $A$ second unexplained characteristic of these basins is the apparent lack of major thermal subsidence despite the abundance of diabase within them. An appealing mechanism is to transport the large quantities of melt from the region of greater extension and heating around the hinge zone to the basins. This provides a common source for the widespread basalts and diabases within the basin while isolating the Mesozoic basins from the major thermal event to the east. The detachment provides a conduit for the mafic material to move from the hinge zone to the basins thereby potentially explaining the basin and hanging wall gravity anomalies.

We have modified the simple shear detachment model to include the emplacement of a layer of mafic material along the detachment. This modified model takes into account both the loading and gravity effect of such a layer. Loading produces a slight regional sag that accentuates the long-wavelength negative gravity effect of the basin and hanging wall. The gravity anomaly resulting from such a diabase layer is a function of the varying density constrast between the layer and the surrounding crust. The portion of the layer closest to the surface has the greatest effect primarily due to the large density contrast between the diabase and the sediments (Figure 9). The deeper portions of the layer have correspondingly smaller gravity effects because of the decrease in the density contrast between the diabase and the upper and lower crust. The result is a skewed positive anomaly with a large positive over the basin and the proximal hanging wall (Figure 9).

The unconstrained variables for this modified model are the thickness of the diabase and the 

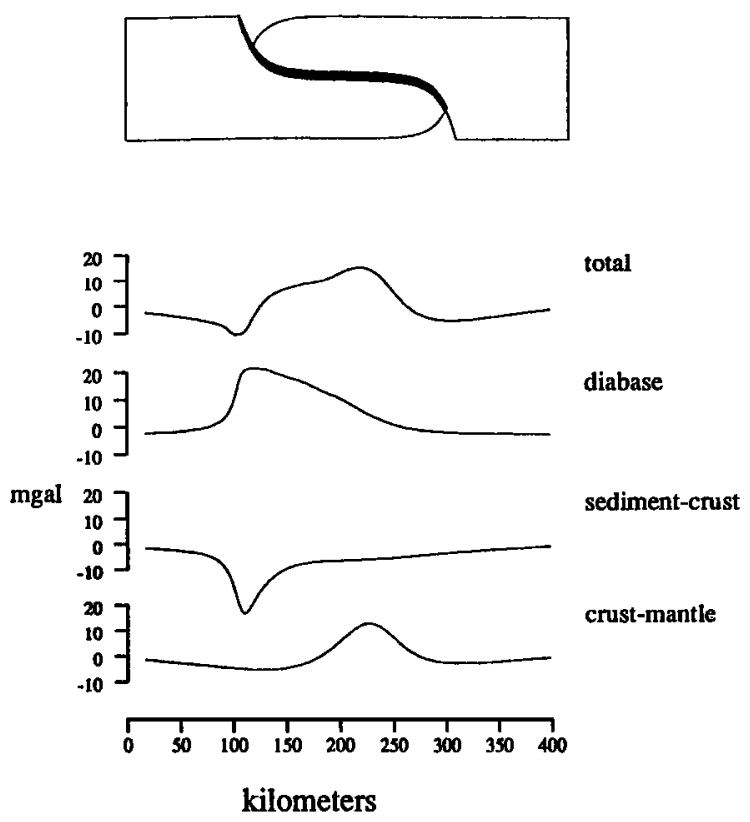

Fig. 9. Schematic of a $2 \mathrm{~km}$ thick diabase body along the detachment and the individual contributions to the total gravity anomaly.

position of the subcrustal extension. Increasing the thickness of the diabase $\left(T_{D}\right)$ increases the amplitude of the inner hanging wall high and decreases the low over the basin (Figure 10a), A diabase thickness of $1.5-2.0 \mathrm{~km}$ reduces the gravity low over the basin to a value close to the observed without requiring any complex basement geometry or any drastic change of infill density.

As before, shifting the location of the subcrustal thinning significantly alters the character of the resultant gravity anomaly. We illustrate the calculated gravity anomaly for a $2 \mathrm{~km}$ thick diabase, varying the distance from the border fault to the outermost region of subcrustal thinning $\left(D_{L}\right)$ from 200 to $50 \mathrm{~km}$ in Figure 10b. A broad 140 $\mathrm{km}$ wide anomaly with two peaks results from a separation of $200 \mathrm{~km}$. As the separation decreases, the two peaks merge into a single narrower peak as the subcrustal positive begins to overlap the negative of the basin. When the surface and subsurface regions of extension are separated by $50 \mathrm{~km}$, only a small positive remains over the basin.

The range of anomalies shown in Figure 10b correlates closely with the observed anomalies across the Newark and Gettysburg basins. Figure 11 shows the filtered profiles with best fitting model results superimposed. $A \mathrm{~T}_{\mathrm{e}}$ of $30 \mathrm{~km}$, an infill density of $2.6 \mathrm{~g} / \mathrm{cm}^{3}$ and a $2 \mathrm{~km}$ thick diabase body were used. Only the location of the subcrustal thinning $\left(D_{\mathrm{L}}\right)$ was allowed to vary. The addition of diabase along the detachment dramatically improves the model fit to the basin and hanging wall anomalies. The model fits best in

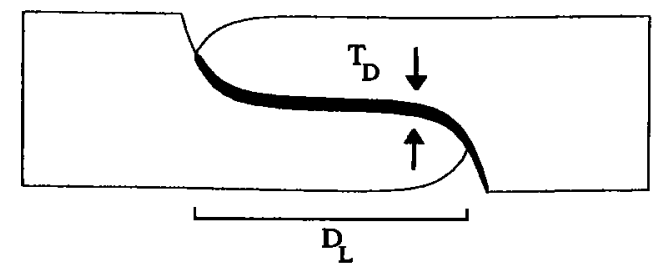

[a]

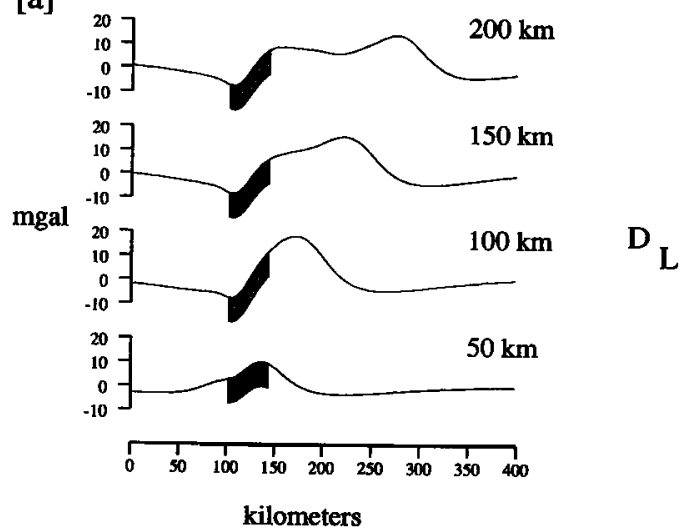

[b]

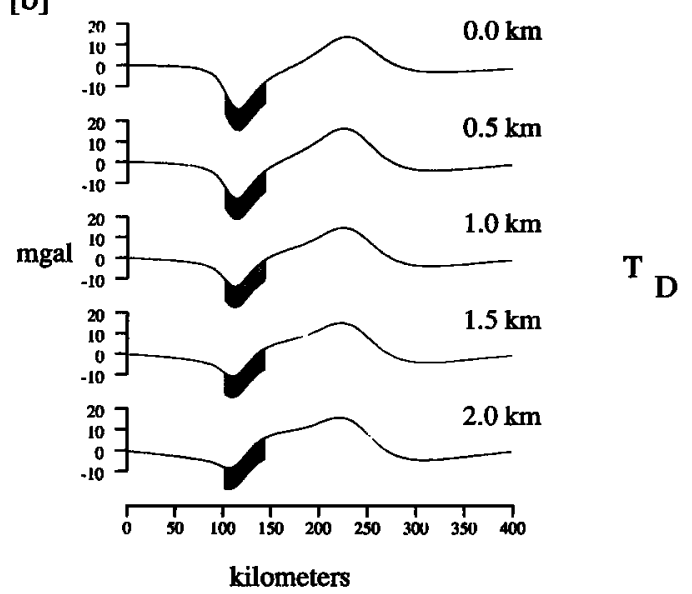

Fig. 10. (a) Gravity effect of allowing the thickness of the diabase layer along the detachment $\left(T_{D}\right)$ to vary. (b) Gravity effect for a model including a $2 \mathrm{~km}$ thick diabase layer, the effect of varying the position of the region of subcrustal extension from the border fault $\left(D_{L}\right)$ from 50 to $200 \mathrm{~km}$. The shading represents the extent of the predicted basin. 


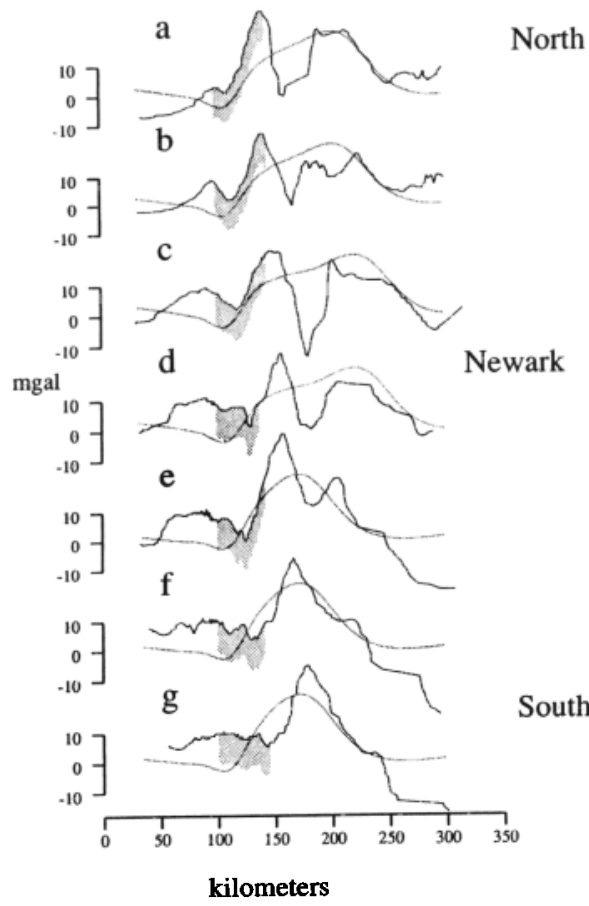

North
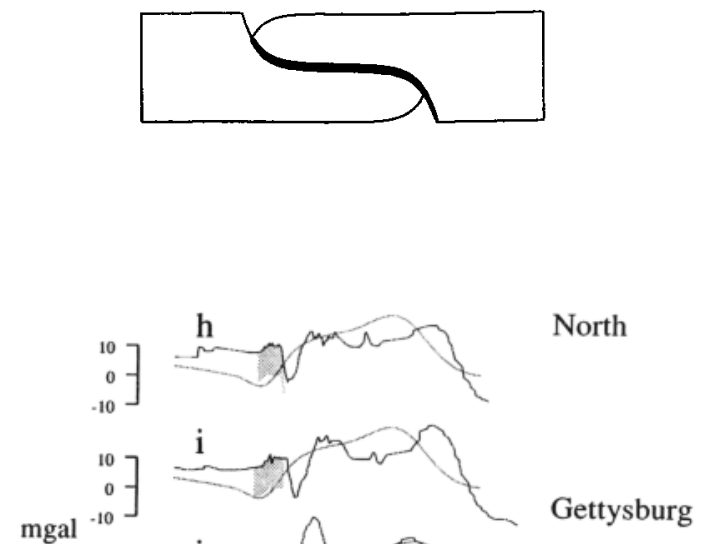

Fig. 11. The results of simple shear detachment model with a $2 \mathrm{~km}$ thick diabase body along the detachment (dashed lines) superimposed upon the filtered profiles (solid lines). Only the distance from the border fault to the region of subcrustal extension $\left(D_{L}\right)$ was allowed to vary.

the Gettysburg basin and the northern Newark basin while the profiles across the southern Newark basin remain problematical. This deterioration of the model fit toward the south probably reflects the more complex basin geometry, the presence of sills at the surface, and the decreasing dip of the border fault.

If the detachment surface is used as a conduit for mafic material, there are several important consequences for both the material within the basins and the dikes intruded into the crust between the hinge zone and the edge of the Blue Ridge front. The conduit model restricts the possible origin of the dikes and sills to a single region, seaward of the hinge zone. Along their full extent, from Nova Scotia to Alabama, the basalts and diabases of the basins, were emplaced synchronously [Sutter, 1988] and are geochemically homogeneous [Puffer, 1984]. A single offshore source region for the mafic material explains both the similarity in timing and chemistry along the $2000 \mathrm{~km}$ extent of the basins. In addition to the mafic material within the basins, there are a large number of early Jurassic dikes within the hanging wall block. The majority of these dikes were emplaced to the east of the Bevard Zone in the Southern Appalachians and seaward of the basin border faults in the mid-
Atlantic region [King, 1961, 1971]. Generally, the early Jurassic dikes are found only in crust underlain by the major thrusts associated with the Paleozoic collisional orogenies that were later reactivated during the Mesozoic opening of the Atlantic. Transporting material from a single offshore source eliminates the need for sufficent heat beneath the entire region to produce melts, thereby explaining the lack of a substantial thermal subsidence phase within these rift basins. The composition of the Mesozoic dikes in the northeast requires a ponding of the magma within the crust [Weigand and Ragland, 1970] which could represent fractionation along the detachment.

\section{CONCLUSIONS}

Flexural rifting models incorporating an intracrustal detachment or a simple shear detachment predict footwall uplift and basin formation across rifts with little or no local thermal anomaly. While these models are sensitive to the differences between local and flexural compensation, they cannot be used to determine an accurate value of $T_{e}$, the effective elastic thickness of the lithosphere.

A flexurally compensated simple shear model 
predicts a gravity high over the hanging wall while local compensation would produce a gravity low. This model is applicable where major thrusts have been normally reactivated. The gravity high predicted by the flexurally compensated model is similar to the outer gravity high over the hanging wall of the Mesozoic basins of eastern North America. This gravity high can be used to locate the region of concentrated extension within the lower crust. The location of the region of concentrated extension that results from modeling the Mesozoic basins corresponds to the previously mapped limits of high stretched crust beneath the continental margin.

However, the model does not fully account for the hanging wall gravity anomaly associated with the Newark and Gettysburg basins. A mass excess across the basin and over the hanging wall block is suggested by both the absence of a significant gravity low over the basin and a residual positive on the proximal hanging wall. The addition of a $2 \mathrm{~km}$ thick diabase layer along the detachment improves the fit of the model by introducing a positive gravity anomaly skewed toward the basin. The addition of this excess mass reduces the basin gravity signature and enhances the hanging wall high without filling the basin with mafic material or calling upon large, preexisting crustal inhomogeneities. The resultant double-peaked gravity anomaly closely matches the observed hanging wall and basin anomalies of the Newark and Gettysburg basins. A single offshore source explains the synchronous emplacement and similar geochemical signature of the mafic material within the basins. The detachment act as a conduit for magma and a probable location for differentiation. It also helps to explain the presence of early Jurassic dikes within the hanging wall block, their general limitation to the east of the Brevard Zone, and the failure of the basin to develop a significant thermal subsidence phase subsequent to rift basin formation.

Acknowledgments. This paper greatly benefited from discussions and reviews by J. Weissel, W. R. Buck, W. C. Burton, W. Bosworth, A. Watts, R. Schlische, P. Olsen, B. Coakley, and an anonymous reviewer. This research was supported by Gas Research Institute contract GRI 5087-2601546, Office of Naval Research contract N0001484-C0132 and a grant from Texaco. LamontDoherty Geological Observatory publication number 4298.

\section{REFERENCES}

Allmendinger, R. W., T. A. Hauge, E. C. Hauser, C. J. Potter, S. L. Klemperer, K. D. Nelson, P.
Knuepfer, and J. Oliver, Overview of the COCORP $40^{\circ} \mathrm{N}$ Transect, western United States: The fabric of an orogenic belt, Geol. Soc. Am. Bull., 98, 308-319, 1987.

Barton, P. J., Comparison of deep reflection and refraction structures in the North Sea, in Reflection Seismology: A Global Perspective, Geodyn. Ser., vol. 13, edited by M. Barazangi and L. Brown, pp. 297-300, AGU, Washington, D.C., 1986.

Beaumont, C., C. E. Keen, and R. Boutilier, On the evolution of rifted continental margins: comparison of models and observations for Nova Scotian margin, Geophys. J. R. Astron. Soc., 70, 667-715, 1982.

British Institutes Reflection Profiling Syndicate (BIRPS) and Etude de la Croûte Continentale et Océanique par Réflexion et Réfraction Sismique (ECORS), Deep seismic reflection profiling between England, France and Ireland, J. Geol. Soc. London, 143, 45-52, 1986.

Bosworth, W., J. Lambiase, and R. Keisler, A new look at Gregory's rift: The structural style of continental rifting, Eos Trans. AGU, 67, 577-583, 1986.

Cook, F.A., Towards an understanding of the southern Appalachian Piedmont crustal transition-A multidisciplinary approach, Tectonophysics, 109, 77-92, 1984.

Eyidogan, H., and J. A. Jackson, Aseismological study of normal faulting in the Demirci, Alasehir and Gediz earthquakes of 1969-70 in western Turkey: implications for the nature and geometry of deformation in the continental crust, Geophys. J., 81, 569-607, 1985.

Froelich, A. J., and P. E. Olsen, Newark Supergroup, a revision of the Newark Group in eastern North America, U.S. Geol. Surv. Bull., 1573A, A55-A58, 1984.

Gibbs, A. D., Structural evolution of extensional basin margins, J. Geol. Soc. London, 141, $609-620,1984$.

Heiskanen, W. A., and F. A. Vening Meinesz, The Earth and its Gravity Field, 470 pp., McGrawHill, New York, 1958.

Hellinger, S. J., and J. G. Sclater, Some comments on two-layer extensional models for the evolution of sedimentary basins, J. Geophys. Res., 88, 8251-8269, 1983.

Hutchinson, D. R., K. D. Klitgord, and R. S. Detrick, Rift basins of the Long Island platform, Geol. Soc. Am. Bull., 97, 688-702, 1986.

Jackson, J., and D. McKenzie, The geometrical evolution of normal fault systems, J. Struct. Geol., 5, 471-482, 1983.

Karner, G. D., and A. B. Watts, On isostasy at Atlantic-type continental margins, J. Geophys. Res., 88, 10,449-10,477, 1983.

Katz, B. J., C. R. Robinson, T. Jorjorian, and, F.D. Foley, The level of organic maturity within 
the Newark Basin and its associated implications, in Triassic-Jurassic Rifting; North America and North Africa, edited by W. Manspeizer, Elsevier Science, New York, in press, 1988.

King, P. B., 1961. Systematic pattern of Triassic dikes in the Appalachian region, Short $P a p$. Geol. Hydrol. Sci., Art. 1-146, B-93-B-95, 1961.

King, P. B., 1971. Systematic pattern of Triassic dikes in the Appalachian region-second report, U.S.G.S. Professional Papers, 750-D, D84-D88.

Kligfield, R., J. Crespi, S. Naruk and G. H. Davis, Displacement and strain patterns of extensional orogens, Tectonics, 3, 577-609, 1984.

Klitgord, K. D., and J. C. Behrendt, Basin structure of the U.S. Atlantic margin, in Geological and geophysical investigations of continental margins, Mem. Am. Assoc. Petr. Geol., 39, 85-112, 1979.

Lake, S. D., and G. D. Karner, The structure and evolution of the Wessex basin. southern England: An example of inversion tectonics, Tectonophysics, 137, 347-378, 1987.

Large Aperture Seismic Experiment (LASE), Deep structure of the U.S. east coast passive margin from large aperture seismic experiments, Mar. Petr. Geol., 3, 234-242, 1986.

Lister, G. S., M. A. Etheridge, and P. A. Symonds, Detachment faulting and the evolution of passive continental margins, Geology, 14, 246-250, 1986.

McClay, K. R., and P. G. Ellis, Geometries of extensional fault systems developed in model experiments, Geology, 15, 341-344, 1987.

McKenzie, D., Some remarks on the development of sedimentary basins, Earth Planet. Sci. Lett., 40, 25-32, 1978.

Petersen, T. A., L. D. Brown, F. A. Cook, S. Kaufman, and J. E. Oliver, Structure of the Riddleville basin from COCORP seismic data and implications for reactivation tectonics, $J$. Geol., 92, 261-271, 1984.

Pratt, L. M., A. R. Vuletich, and T. E. Daws, Geochemical and isotopic characterization of organic matter in rocks of the Newark Supergroup, in Proceedings of Second U.S. Geological Survey Workshop on the Early Mesozoic basins of the Eastern United States, U.S. Geol. Surv. Circ., 946, edited by G.P. Robinson and A.J. Froelich, pp. 74-78, Reston, Va., 1985.

Puffer, J. H., Relationships among eastern North America tholeiites, in Geological Association of New Jersey Guidebook, vol. 1, pp. 16-44, 1984.

Ratcliffe, N. M., and W. C. Burton, Fault reactivation models for origin of the Newark basin and studies related to eastern U.S. seismicity, in Proceedings of second U.S. Geological Survey Workshop on the Early Mesozoic basins of the Eastern United States, U.S. Geol. Surv. Circ. 946, edited by G.P. Robinson and A.J. Froelich, pp. 36-45, Reston, Va., 1985.
Ratcliffe, N. M., and J. K. Costain, Semi-annual progress report to earthquake hazards reduction program, U.S. Geol. Surv. Open File Rep., 85464, 54-58, 1985.

Ratcliffe, N. M., W. C. Burton, R. M. D'Angelo, and J. K. Costain, Low-angle extensional faulting, reactivated mylonites, and seismic reflection geometry of the Newark basin margin in eastern Pennsylvania, Geology, 14, 766-770, 1986.

Rowley, D. B., and D. Sahagian, Depth-dependent stretching: A different approach, Geology, 14, 32-35, 1986.

Royden, L., and C. E. Keen, Rifting process and thermal evolution of the continental margin of eastern Canada determined from subsidence curves, Earth Planet. Sci. Lett., 51, 343-361, 1980.

Sclater, J.G., and P.A. Christie, Continental stretching: An explanation of the post MidCretaceous subsidence of the Central North Sea basin, J. Geophys. Res., 85, 3711-3739, 1980.

Sleep, N. H., Thermal effects of the formation of Alantic continental margins by continental breakup, Geophys. J. R. Astron. Soc., 24, 325-350, 1971.

Spencer, J. E., Role of tectonic denudation in warping and uplift of low angle normal faults. Geology, 12, 95-98, 1984.

Steckler, M. S., and A. B. Watts, Subsidence of the Atlantic type continental margin off New York, Earth Planet. Sci. Lett., 42, 1-13, 1978.

Steckler, M. S. and A. B. Watts, The Gulf of Lion: Subsidence of a young continental margin, Nature, 287, 425-429, 1980.

Sumner, J. R., Geophysical investigation of the structural framework of the Newark-Gettysburg Triassic basin, Pennsylvania, Geol. Soc. Am. Bull., 88, 935-942, 1977.

Sutter, J. F., Innovative approaches to dating of igneous events in the Early Mesozoic basins, U.S. Geol. Surv. Bull., 1988

Swanson, M. T., Preexisting fault control for Mesozoic basin formation in eastern North America, Geology, 14, 419-422, 1986.

Vening Meinesz, F. A., Les graben Africains, resultat de compression ou de tension dans la croute terrestre?, Bull. Inst. R. Colon. Belge, 21, 539-552, 1950.

Watts, A. B. and M. S. Steckler, Subsidence and eustasy at the continental margin of eastern North America, in Deep Drilling Results in the Atlantic Ocean: Continental Margins and Paleoenvironment, Geophys. Monogr. Ser., vol. 3, edited by M. Talwani et al., pp. 218-234, AGU, Washington, D.C., 1979.

Watts, A. B., G. D. Karner, and M. S. Steckler, Lithospheric flexure and the evolution of sedimentary basin, Philos. Trans. R. Soc. London, 305a, 249-281, 1982.

Weigand, P. W., and P. C. Ragland, Geochemistry of Mesozoic dolerite dikes from Eastern North 
America, Contrib. Mineral. Petrol., 29, 195-214, 1970.

Wernicke, B., Low-angle normal faults in the Basin and Range Province: Nappe tectonics in an extending orogen, Nature, 291, 645-647, 1981.

Wernicke, B., Uniform-sense normal simple shear of the continental lithosphere, Can. J. Earth Sci., 22, 108-125, 1985.

Wernicke, B., and B. C. Burchfiel, Modes of extensional tectonics, J. Struct. Geol., 4, 105-115, 1982.
Zandt, G., and T. J. Owens, Crustal flexure associated with normal faulting and implications for seismicity along the Wasatch Front, Utah, Bull. Seismol. Soc. Am., 70, 1501-1520, 1980.

R. E. Bell ${ }^{1}$, G. D. Karner, and M. S. Steckler Lamont-Doherty Geological Observatory of Columbia University, Palisades, New York, 10964.

(received October 21, 1987;

revised February 3, 1988;

accepted February 5, 1988.) 